\title{
Rediscovery of Stephanomeria (Rush Pink) in Saskatchewan
}

\author{
by John H. Hudson, Saskatoon
}

The yearly field meeting of the Saskatchewan Natural History Society held southeast of Beechy on 6 and 7 June, 1964, was made memorable for me by discovering on the Saturday journey a "new skeleton-weed" in the shale badlands of the valley sides.

The plant came to my notice by differing from our everyday Purple Skeleton-weed (Lygodesmia juncea) in having at least the basal leaves pinnatifid (with comb-like teeth to the leaves) rather than linear and entire if present at all When I found the milky sap to be white instead of yellowgreen (as is that of Purple Skeletonweed) I knew something unusual had turned up. No flowers further advanced than mere buds could be found, but I collected the material anyway, on NW $6-20-11 w 3,1 / 2$ mile north of the "Sinking Hill." As a preliminary guess it seemed to agree with the description of Stephanomeria tenuifolia (Torr.) Hall, Rush Pink, in Moss (1959).

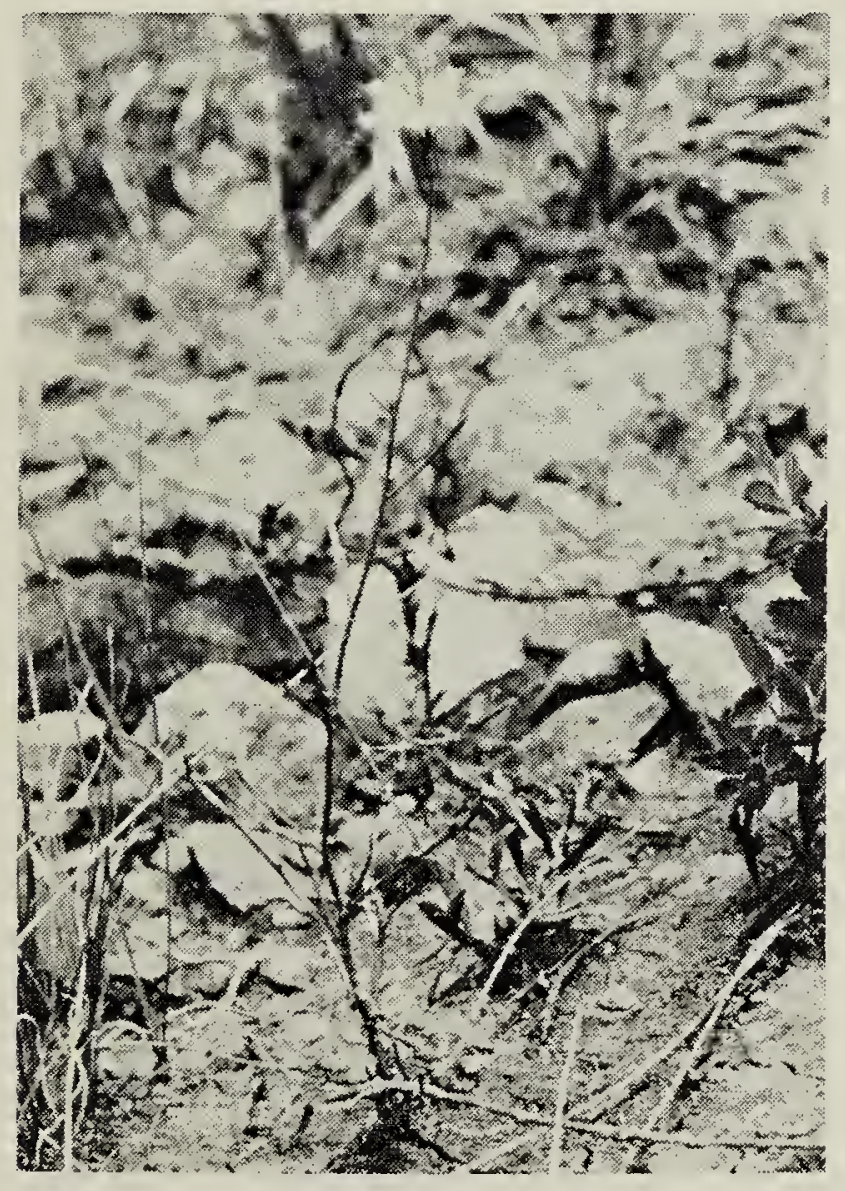

Conversion from kodachrome by $G$. F. Ledingham

Rush Pink, above Frenchman River, June 28, 1964
Sunday morning Dr. G. F. Ledingham and I went out southeast from the camp hoping to run into the plant in flower. No luck; plenty of Stephanomeria, but no flowers. We observed, however, that is is rigidly confined to powder-shale beds-that is, beds of loose flaky non-swelling clays which in the outcrop break down to a powder and lie at the angle of repose for loose sand. It does not grow on bentonitis (i.e., gumbo-like) beds. This could be of interest to geologists.

Later on in the summer (16 August) I got back to the camp area and collected the plant as J. H. Hudson \#2211 on SE 7-21-9 w3. Much fruiting material and a few belated flowers were found. Specimens have been distributed to the Department of Agriculture at Ottawa and to the Fraser Herbarium in Saskatoon.

There is some doubt as to the right specific name for this material. Cronquist's key (1955) gives one a choice between Stephanomeria runcinata Nutt. with pinnatifid leaves and achenes pitted, tuberculate, and grooved, and Stephanomeria tenuifolia (Torr.) Hall with leaves merely toothed, and ribbed achenes. My material has pinnatifid leaves but ribbed achenes. I have distributed it as $S$. runcinata on the strength of the pinnatifid leaves. However, Alberta material has been reported by Moss (1959) and North Dakota material by Stevens (1961) as $S$. tenuifolia. One would expect that all these reports to concern the same species. This is one for the specialists.

This article has been entitled "rediscovery," not "discovery." It turns out that G. M. Dawson of the Geological Survey of Canada, while on the Boundary Survey of 1873-74 (Dawson, 1875) got this plant, under the name of Stephanomeria minor Nutt. on June 29, 1874, from a "dry clay bank south of Wood Mountain." This would be in the Morgan Creek badlands west of Killdeer. The ironic point is that George Ledingham and I visited these outcrops on May 29, 1955. While there I remember seeing some odd-looking basal rosettes with milky 
juice, and calling George's attention to them. We dismissed them as young Blue Lettuce, never asking ourselves just what Blue Lettuce would be doing on shale badlands. I'm sure now that these were Stephanomeria.

The following table will help to distinguish Stephanomeria from the two Saskatchewan skeleton-weeds, in case anyone is interested in finding it in their areas. Dr. G. W. Argus of the Fraser Herbarium (described in the June, 1964, issue of the Blue Jay) would be pleased to receive specimens. Going by geology it should occur southeast of Val Marie along the Frenchman River, and perhaps along Battle Creek near Merryflat, as well as at Morgan Creek. In fact, George
Ledingham collected it along the Frenchman on June 28, 1964-a few weeks after our discovery at Beechy (see photo).

The flowers are not mentioned in the table. All three species have similar thin-cylindric flower heads which have about five pink rays roughly onehalf inch long.

\section{LITERATURE CITED}

Cronquist, A. 1955. Vascular plants of the Pacific Northwest, Part 5, Compositae page 314. University of Washington Press, Seattle.

Dawson, G. M. 1875. Report on the geology and resources of the region in the vicinity of the forty-ninth parallel. Appendix F. page 366. Montreal, Dawson Brothers.

Moss, E. H. 1959. Flora of Alberta, p. 499. University of Toronto Press.

Stevens, O. A. 1961. New records for North Dakota. Rhodora, 63, 39-46.

SEPARATION OF SKELETON-WEEDS

\begin{tabular}{|c|c|c|c|}
\hline Names & $\begin{array}{l}\text { Lygodesmia juncea } \\
\text { Purple Skeleton-weed }\end{array}$ & $\begin{array}{l}\text { Lygodesmia rostrata } \\
\text { Annual Skeleton-weed }\end{array}$ & $\begin{array}{l}\text { Stephanomeria } \\
\text { runcinata (Rush Pink) }\end{array}$ \\
\hline Leaves & $\begin{array}{l}\text { Linear and entire, } \\
\text { often reduced to } \\
\text { scales or lacking. }\end{array}$ & $\begin{array}{l}\text { Linear and entire, } \\
\text { well-developed. }\end{array}$ & $\begin{array}{l}\text { Pinnatifid to merely } \\
\text { toothed, well-devel- } \\
\text { oped. }\end{array}$ \\
\hline Roots & $\begin{array}{l}\text { Perennial from deep } \\
\text { running } \mathrm{r} h \mathrm{i} z \text { o m e s } \\
\text { (root-stocks). }\end{array}$ & $\begin{array}{l}\text { Annual from a tap- } \\
\text { root. }\end{array}$ & $\begin{array}{l}\text { Authorities state a } \\
\text { caudex (woody tap- } \\
\text { root) to be present; } \\
\text { our material, how- } \\
\text { ever, has well-devel- } \\
\text { oped creep ing } \\
\text { rhizomes. }\end{array}$ \\
\hline Milky juice & $\begin{array}{l}\text { Yellow-green, a fact } \\
\text { not mentioned in } \\
\text { floras. }\end{array}$ & White. & White. \\
\hline $\begin{array}{l}\text { Pappus } \\
\text { (seed cotton) }\end{array}$ & $\begin{array}{l}\text { Simple (hairs un- } \\
\text { branched) pale } \\
\text { brown. }\end{array}$ & Simple, white. & $\begin{array}{l}\text { Plumose (hairs with } \\
\text { featherlike branch- } \\
\text { ing), white. }\end{array}$ \\
\hline Distribution & $\begin{array}{l}\text { Dry places through- } \\
\text { out prairie Saskat- } \\
\text { chewan. }\end{array}$ & $\begin{array}{l}\text { Southwest only, open } \\
\text { sand. }\end{array}$ & $\begin{array}{l}\text { Southwest only, pow- } \\
\text { der shale badlands. }\end{array}$ \\
\hline
\end{tabular}

\section{Additional Notes on Common Mullein}

\section{at Saskatoon in 1964 by Williom s. Richords, Soskotoon}

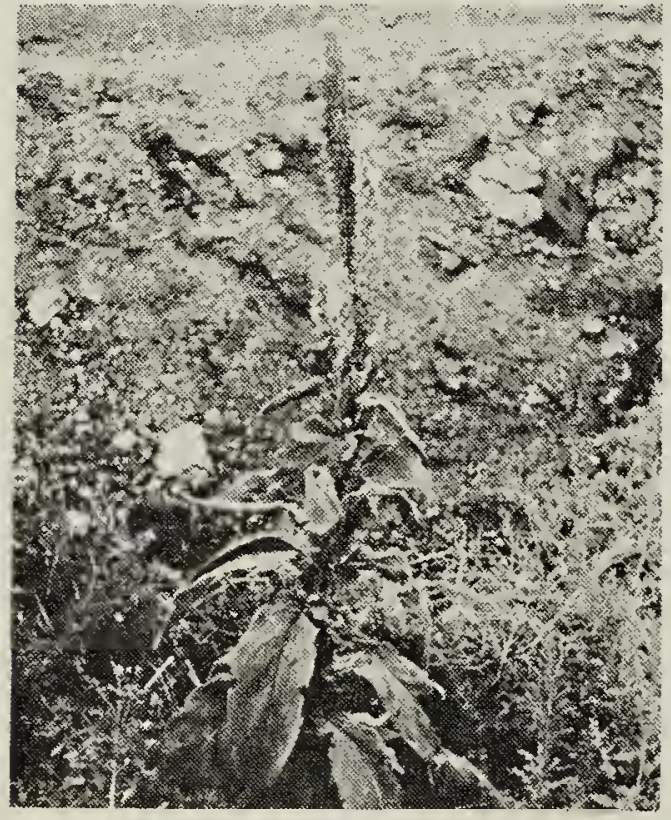

Common Mullein, Saskatoon, 1964
Since the first report of Common Mullein, Verbascum thapsus $\mathbf{L}$. in Saskatchewan by J. H. Húdson (Blue Jay, March, 1962) there has been a further report of this plant occurring at Moose Jaw by Mrs. MacGillivray (Blue Jay, June, 1962). The accompanying photo shows a flowering specimen growing at Saskatoon in September, 1964.

During the summer of 1963 I revisited the site where I first found this plant growing, and although I thought I had made a thorough search of the area, I was unable to locate any first year rosettes or second year spikeheads. However, in 1964 I returned 